\title{
PENGARUH INTELLECTUAL CAPITAL, TATA KELOLA PERUSAHAAN DAN KUALITAS AUDIT TERHADAP MANAJEMEN LABA
}

\author{
Nawang Kalbuana ${ }^{1)}$, Nita Yulistian ${ }^{2)}$, A. Nugroho Budi $\mathbf{R}^{3 \text { ) }}$ \\ Politeknik Penerbangan Indonesia Curug ${ }^{1,3}$, Institut Teknologi dan Bisnis \\ Ahmad Dahlan Jakarta ${ }^{2}$ \\ Email : nawang.kalbuana@stpicurug.ac.id, nitayulistiani39@gmail.com; \\ anugroho.budi@stpicurug.ac.id
}

\begin{abstract}
Earnings management is defined as earnings engineering activities / actions with certain objectives carried out by management. This research is expected to obtain empirical evidence of the influence of intellectual capital, corporate governance and audit quality in influencing earnings management in transportation companies and was listed on the Indonesia Stock Exchange in 2014-2018. Data was collected using a purposive sampling method and there were 14 companies that met the research criteria and carried out by testing the multiple linear regression hypothesis through the application of SPSS 23. In this study produced variables of intellectual capital, corporate governance and audit quality simultaneously have an influence on earnings management. While partially only intellectual capital variables that affect earnings management. Companies that are audited by large KAPs may not be able to limit the occurrence of earnings management actions. The large share ownership should be able to make the institutional control of operational activities, but the reality of institutional ownership is not able to limit the existence of earnings management

Theoretical implications expected from research are able to make intellectual capital as one indicator in measuring the occurrence of earnings management in future research.
\end{abstract}

Keywords: Intellectual Capital; Institutional Ownership; Managerial Ownership; Audit Quality; Earnings Management

\begin{abstract}
Abstrak
Manajemen laba diartikan kegiatan/tindakan perekayasaan laba dengan tujuan tertentu yang dilakukan oleh pihak manajemen. Penelitian yang dilakukan ini diharapkan untuk mendapatkan bukti empiris pengaruh intellectual capital, tata kelola perusahaan serta kualitas audit dalam mempengaruhi manajemen laba pada perusahaan transportasi dan terdaftar dalam Bursa Efek Indonesia pada tahun 2014-2018. Pengambilan data dilakukan dengan menggunakan metode purposive sampling dan terdapat 14 perusahaan yang memenuhi kriteria penelitian dan dilakukan dengan uji hipotesis regresi linier berganda melalui aplikasi SPSS 23.
\end{abstract}

* Corresponding author's e-mail: nawang.kalbuana@stpicurug.ac.id

http://openjournal.unpam.ac.id/index.php/JABI 
Jurnal Akuntansi Berkelanjutan Indonesia - Vol. 3, No. 1, Jan 2020 - Kalbuana;

Yulistian \& Budi

Dalam penelitian ini menghasilkan variabel intellectual capital, tata kelola perusahaan serta kualitas audit secara simultan memiliki pengaruh terhadap manajemen laba. Sedangkan secara parsial hanya variabel intellectual capital yang berpengaruh terhadap manajemen laba. Perusahaan yang diaudit oleh KAP besar belum tentu dapat membatasi terjadinya tindakan manajemen laba. Besarnya kepemilikan saham seharusnya mampu membuat pihak institusional mengontrol kegiatan operasional, namun realitanya kepemilikan institusional tidak mampu membatasi adanya manajemen laba. Implikasi secara teoritis yang diharapkan dari penelitian mampu menjadikan intellectual capital sebagai salah satu indikator dalam mengukur terjadinya manajemen laba di penelitian yang akan datang.

Kata Kunci: Intellectual Capital; Kepemilikan Institusional; Kepemilikan Manajerial; Kualitas Audit; Manajemen Laba

\section{PENDAHULUAN}

Pertengahan tahun 2019 terjadi kisruh mengenai manipulasi laporan keuangan pada perusahaan transportasi udara yang sangat dikenal di Indonesia (PT Garuda Indonesia Tbk). Dony O. dan Chairal T. selaku komisaris Garuda, melakukan penolakan untuk penandatanganan laporan keuangan Perusahaan. Dony dan Chairal mengaku keberatan dengan pengakuan pendapatan sebesar USD 239,94 juta yang berasal dari perjanjian kerja sama PT Citilink Indonesia selaku entitas anak Garuda Indonesia dengan PT Mahata Aero Teknologi (Mahata) terkait debfab layanan konektivitas. Menurut mereka, meskipun sudah terpasangnya satu unit alat di Citilink belum saatnya Garuda mengakui pendapatan tersebut karena merujuk pada Perjanjian Mahata yang belum melakukan pembayaran oleh pihak Mahata (Prastowo, 2019). Kasus serupa yang pernah terjadi di negara kita yakni pada PT Bank Lippo Tbk. Kondisi tersebut terjadi ketika manajemen PT Bank Lippo melaporkan aset sebesar Rp 22,8 triliun, rugi bersih sebesar Rp1,2 triliun serta rasio CAR (kecukupan modal) 4,2\% dalam laporan keuangan triwulan 3 tahun 2002 ke Bursa Efek Jakarta (BEJ). Sementara sebulan sebelumnya, PT Bank Lippo menerbitkan/mengeluarkan laporan keuangan yang berbeda nilainya, yaitu aset Rp24 triliun, laba bersih sebesar Rp 99 miliar serta rasio CAR 24,8\% (Khairani \& Wimelda, 2017).

Kasus di atas merupakan kasus yang berkaitan dengan penyajian laporan keuangan (Financial Report), dalam hal ini laporan keuangan diartikan sebagai output yang dihasilkan dari pihak manajemen yang memuat informasi terkait dengan posisi keuangan (neraca), kinerja perusahaan dalam periode tertentu yang diperuntukkan bagi pihak yang memerlukan untuk mengambil keputusan ekonomi (Agustia, 2013). Penyajian laporan keuangan sangat disarankan untuk dilakukan pengungkapan secara penuh (full disclosure) dan transparan sehingga tidak menyesatkan pembaca laporan keuangan (Antonia, 2008). Auditor yang berkualitas dan mumpuni diperlukan untuk meningkatkan kualitas dan relevan

* Corresponding author's e-mail: nawang.kalbuana@stpicurug.ac.id

http://openjournal.unpam.ac.id/index.php/JABI 
Jurnal Akuntansi Berkelanjutan Indonesia - Vol. 3, No. 1, Jan 2020 - Kalbuana;

Yulistian \& Budi

serta aktualnya laporan keuangan. Auditor yang mempunyai kredibilitas yang baik akan selalu berhati-hati dalam mengaudit laporan keuangan dan mendeteksi apabila terjadi salah saji ataupun kecurangan (Wiryadi \& Sebrina, 2013).

Tidak jarang manajemen melakukan tindakan manipulasi laporan keuangan untuk tujuan tertentu. Cara paling banyak yang dilakukan manajemen dengan memanipulasi keuntungan/laba perusahaan baik itu dengan menaikkan laba di tahun ini, maupun membuat cadangan laba di tahun berikutnya. Manajemen laba mampu menimbulkan permasalahan keagenan yang dimulai dari adanya peran pemegang saham dan pengelola perusahaan perusahaan. Manajemen selaku pihak agen mempunyai informasi yang lebih banyak dibandingkan pihak principal sehingga asimetri informasi yang terjadi memungkinkan pihak agen/manajemen melakukan praktik manajemen laba (Herawaty, 2008).

Perusahaan yang baik mempunyai tata kelola perusahaan yang mampu meminimalisir praktik manajemen laba melalui proses pengawasan dengan memisahkan kepentingan pemilik perusahaan dan manajemen dengan membedakan jenis struktur kepemilikan saham menjadi milik manajer dan institusi (Herawaty, 2008). Kepemilikan manajerial diduga dapat meminimalisir praktik manajemen laba dikarenakan pemegang saham yang sekaligus sebagai manajer perusahaan akan diukur oleh pihak lain dalam kontrak sehingga diharapkan manajemen termotivasi menyusun laporan keuangan yang berkualitas. Sedangkan kepemilikan institusional diharapkan mampu memberikan mekanisme pengawasan yang serupa karena adanya kepemilikan saham oleh pihak institusi (Mahariana \& Ramantha, 2014).

Modal intelektual atau intellectual capital merupakan suatu konsep yang terbagi dalam 3 kategori yakni structural capital, human capital serta customer capital untuk menambah suatu nilai yang berharga bagi perusahaan (Yudhanti \& Shanti, 2011). Boekestein (2006) berpendapat bahwa human capital diartikan sebagai pengetahuan yang dimiliki karyawan, sedangkan structural capital sebagi pengetahuan yang terkait dengan entitas/perusahaan, serta customer capital terkait dengan pelanggan (Ulum, 2009). Peran modal intelektual semakin strategis bahkan menjadi peran utama/penting dalam upaya meningkatkan nilai perusahaan. Hal tersebut dikarenakan dengan menganggap modal intelektual sebagai landasan bagi pertumbuhan perusahaan (Fatima, 2012).

Berdasarkan pada uraian sebelumnya, penulis merumuskan permasalahan:

a. Pengaruh intellectual capital, kepemilikan institusional, kepemilikan manajerial, serta kualitas audit secara simultan terhadap manajemen laba?

b. Pengaruh intellectual capital secara parsial terhadap manajemen laba?

c. Pengaruh kepemilikan institusional secara parsial terhadap manajemen laba?

d. Pengaruh kepemilikan manajerial secara parsial terhadap manajemen laba?

e. Pengaruh kualitas audit secara parsial terhadap manajemen laba?

Diharapkan penelitian ini mampu memperoleh bukti empiris dari pengaruh intellectual capital, kepemilikan institusional, kepemilikan manajerial serta kualitas audit terhadap manajemen laba khususnya pada perusahaan transportasi di Indonesia.

* Corresponding author's e-mail: nawang.kalbuana@stpicurug.ac.id

http://openjournal.unpam.ac.id/index.php/JABI 
Jurnal Akuntansi Berkelanjutan Indonesia - Vol. 3, No. 1, Jan 2020 - Kalbuana;

Yulistian \& Budi

\section{KERANGKA TEORITIS DAN PENGEMBANGAN HIPOTESIS}

Definisi stakeholder oleh Freeman dan Reed (1983, h.91) dalam Ulum (2009) merupakan kelompok/individu yang berpengaruh/dipengaruhi dalam mencapai tujuan organisasi. Berdasarkan teori ini, manajemen organisasi menjalankan aktivitas untuk kemudian melaporkannya kepada stakeholder. Stakeholder berhak mendapatkan informasi dari manajemen terkait aktivitas mereka, meskipun informasi tersebut dapat digunakan atau mungkin tidak digunakan, baik stakeholder tersebut terlibat langsung maupun tidak dalam peran aktivitas organisasi. Teori stakeholder bertujuan untuk meningkatkan nilai dari aktivitas organisasi serta meminimalisir kerugian para stakeholder yang mungkin timbul/terjadi pada saat korporasi dan stakeholder menjalankan hubungan mereka (Ulum, 2009).

Menurut Jensen dan Meckling (1976) teori ini didasari atas hubungan keagenan antara manajer sebagai agent dan investor sebagai principal dalam sebuah kontrak. Akibat dari hubungan kontrak antara investor dan agent tersebut, manajer dapat melakukan kegiatan yang tidak diinginkan investor sehingga memungkinkan timbulnya biaya keagenan (Agustia, 2013). Biaya keagenan ini meliputi monitoring cost yaitu pengeluaran yang dilakukan investor agar perilaku manajer masih dalam pengawasannya, bonding cost yaitu pengeluaran untuk menjamin manajer untuk tidak melakukan perihal yang mampu merugikan investor, dan residual loss yaitu prosentasi turunnya tingkat kesejahteraan setelah adanya hubungan keagenan. Konflik keagenan ini mampu menimbulkan asimetri informasi yang disebabkan oleh pihak manajer. Asimetri informasi dapat diartikan sebagai kondisi atau keadaan dimana terdapat perbedaan informasi yang diperoleh sehingga mengakibatkan tidak seimbangnya informasi antara manajer dan investor. Diperlukan pihak penengah antara manajer dan investor yang dapat mengontrol dan mengawasi kinerja manager (sebagai agen) agar sesuai dengan keinginan investor (prinsipal) (Khairani \& Wimelda, 2017).

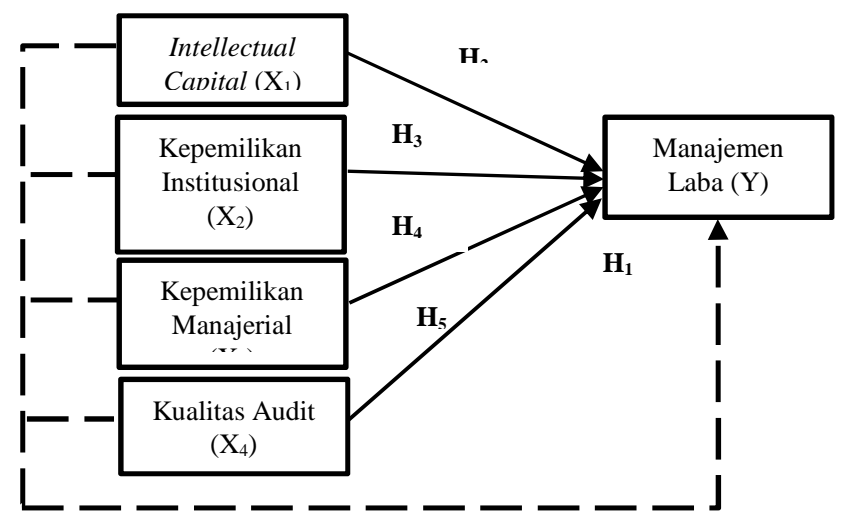

Gambar 1: Kerangka Pemikiran

* Corresponding author's e-mail: nawang.kalbuana@stpicurug.ac.id http://openjournal.unpam.ac.id/index.php/JABI 
Jurnal Akuntansi Berkelanjutan Indonesia - Vol. 3, No. 1, Jan 2020 - Kalbuana;

Yulistian \& Budi

Berikut hipotesis penelitian yang dapat dirumuskan dari uraian di atas:

$\mathrm{H}_{1}$ : Intellectual capital, kepemilikan institusional, kepemilikan manajerial dan kualitas audit, secara simultan berpengaruh terhadap manajemen laba

$\mathrm{H}_{2}$ : Intellectual capital berpengaruh terhadap manajemen laba

$\mathrm{H}_{3}$ : Kepemilikan institusional berpengaruh terhadap manajemen laba

$\mathrm{H}_{4}$ : Kepemilikan manajerial berpengaruh terhadap manajemen laba

$\mathrm{H}_{5}$ : Kualitas audit berpengaruh terhadap manajemen laba

\section{METODE RISET}

Data sekunder yang digunakan dalam penelitian ini berupa laporan keuangan perusahaan transportasi yang terdaftar di BEI serta diakses pada www.idx.co.id. Adapun laporan keuangan yang digunakan sebagai sampel periode 2014 - 2018. Populasi penelitian berjumlah 45 perusahaan dengan teknik purposive sampling. Pemilihan sampel yang diambil meliputi:

1. Perusahaan transportasi yang terdaftar di BEI tahun 2014-2018

2. Perusahaan transportasi secara konsisten menerbitkan laporan keuangan periode $2014-2018$

3. Perusahaan transportasi yang menyajikan laporan keuangan dengan mata uang rupiah

Tabel 1: Sampel Penelitian

\begin{tabular}{lcc}
\hline \multicolumn{1}{c}{ Keterangan } & $\begin{array}{c}\text { Jumlah } \\
\text { Perusahaan }\end{array}$ & Jumlah Data \\
\hline $\begin{array}{l}\text { Perusahaan transportasi yang terdaftar di Bursa Efek } \\
\text { Indonesia pada tahun 2014-2018 }\end{array}$ & 45 & 171 \\
$\begin{array}{l}\text { Perusahaan transportasi yang tidak konsisten } \\
\text { menerbitkan laporan keuangan berakhir pada tahun }\end{array}$ & $(15)$ & $(22)$ \\
$2014-2018$ & & \\
$\begin{array}{l}\text { Perusahaan transportasi yang menerbitkan laporan } \\
\text { keuangan dengan mata uang selain rupiah pada tahun } \\
\text { 2014-2018 }\end{array}$ & $(15)$ & $(74)$ \\
$\begin{array}{l}\text { Perusahaan transportasi yang tidak memiliki beban } \\
\text { karyawan berdasarkan laporan keuangan tahun 2014- }\end{array}$ & $(1)$ & \\
$\begin{array}{l}\text { 2018 } \\
\quad \text { Total sampel penelitian selama 2014 - 2018 }\end{array}$ & $\mathbf{1 4}$ & $\mathbf{7 0}$ \\
\hline
\end{tabular}

* Corresponding author’s e-mail: nawang.kalbuana@stpicurug.ac.id http://openjournal.unpam.ac.id/index.php/JABI 
Jurnal Akuntansi Berkelanjutan Indonesia - Vol. 3, No. 1, Jan 2020 - Kalbuana;

Yulistian \& Budi

\section{Definisi Operasional dan Pengukuran Variabel Intellectual Capital}

Dalam Sawarjuwono \& Kadir (2003), modal intelektual atau intellectual capital merupakan perpaduan dari human capital, structural capital dan customer capital dan terkait dengan pengetahuan dan teknologi guna meningkatkan nilai lebih perusahaan untuk bersaing secara global. Variabel intellectual capital diukur menggunakan koefisien VAIC ${ }^{\mathrm{TM}}$ milik pulik yang dikembangkan oleh Ulum (2009) dengan menghitung dan mencari persamaan berikut:

Tahap pertama: mencari Value Added (VA)

Keterangan:$$
=-
$$

VA : Value Added

OUT : Output (total penjualan dan pendapatan lain)

IN : Input (beban penjualan dan biaya lain selain beban karyawan)

Tahap kedua: menghitung Value Added Capital Employed (VACA)

Keterangan:

VACA : Value Added Capital Employed

VA : Value Added

CE : Capital Employed (dana yang tersedia; ekuitas)

Tahap ketiga: menghitung Value Added Human Capital (VAHU)

Keterangan:

VAHU : Value Added Human Capital

VA : Value Added

HC : Human Capital (beban karyawan)

Tahap keempat: menghitung Structural Capital Value Added (STVA)

Keterangan:

$$
=\quad /
$$

STVA : Structural Capital Value Added

SC $\quad$ : Structural Capital (VA - HC)

VA : Value Added

Tahap kelima: menghitung Value Added Intellectual Coefficient (VAICTM) dari ketiga koefisien diatas.

$$
{ }^{\mathrm{TM}}=\quad+\quad+
$$

\section{Kepemilikan Institusional}

Kepemilikan institusional dapat diartikan sebagai kepemilikan saham suatu perusahaan oleh pihak lain dari luar perusahaan. Saham tersebut dapat dimiliki oleh pihak yang tidak mudah percaya oleh manajemen perusahaan seperti pemerintah, bank, investor, asuransi, dana pensiun dan sebagainya (Khairani \&

* Corresponding author's e-mail: nawang.kalbuana@stpicurug.ac.id http://openjournal.unpam.ac.id/index.php/JABI 
Jurnal Akuntansi Berkelanjutan Indonesia - Vol. 3, No. 1, Jan 2020 - Kalbuana;

Yulistian \& Budi

Wimelda, 2017). Variabel ini diukur menggunakan rasio perbandingan jumlah saham yang dimiliki pihak institusional dengan total modal saham perusahaaan (Guna \& Herawaty, 2010).

$$
\text { INST }=\frac{\text { Jumlah saham yang dimiliki pihak institusional }}{\text { Total modal saham perusahaan yang beredar }}
$$

\section{Kepemilikan Manajerial}

Kepemilikan manajerial merupakan saham yang dimiliki secara pribadi oleh pihak manajemen maupun entitas anak perusahaan. Variabel ini diukur menggunakan rasio perbandingan antara jumlah saham yang dimiliki oleh pihak manajemen dengan total modal saham perusahaan yang beredar (Guna \& Herawaty, 2010).

$$
\text { MNJR }=\frac{\text { Jumlah saham yang dimiliki pihak manajerial }}{\text { Total modal saham perusahaan yang beredar }}
$$

\section{Kualitas Audit}

Kualitas audit diproksikan dengan Kantor Akuntan Publik (KAP) big four dengan menggunakan variabel dummy. Laporan keuangan yang diaudit oleh salah satu KAP big four diberikan skor 1 dan skor 0 apabila laporan keuangan diaudit oleh KAP selain big four. (Wiryadi \& Sebrina, 2013)

\section{Manajemen Laba}

Manajemen laba merupakan tindakan manajemen dalam memanipulasi laba baik dengan menurunkan atau menaikkan laba dalam laporan keuangan dengan tujuan tertentu (Scott, 2011). Manajemen laba dalam penelitian ini diukur menggunakan Modified Jones Model dengan mengidentifikasi nilai discretionary accrual (Dechow et al, 1995). Discretionary accruals dihitung dengan menggunakan rumus dibawah ini.

Tahap pertama: mencari Total Accrual (TA)

$$
\mathbf{T A}_{\text {it }}=\mathrm{NI}_{\text {it }}-\mathrm{CFO}_{\text {it }}
$$

Keterangan:

$\mathrm{TA}_{\mathrm{it}} \quad$ : Total Accrual perusahaan i tahun $\mathrm{t}$

$\mathrm{NI}_{\mathrm{it}} \quad$ : Net Income (laba bersih sebelum pajak tahun $\mathrm{t}$ )

$\mathrm{CFO}_{\text {it }}$ : Cash Flow Operation (arus kas operasi t)

Tahap kedua: mengestimasikan Total Accrual $\left(\mathrm{TA}_{\mathrm{it}}\right)$ dengan Ordinary Least Square (OLS) untuk memperoleh nilai koefisien regresi.

$$
\mathrm{TA}_{\mathrm{it}} / \mathrm{A}_{\mathrm{it}-1}=\beta_{1}\left(1 / \mathrm{A}_{\mathrm{it}-1}\right)+\beta_{2}\left(\Delta \operatorname{Rev}_{\mathrm{it}} / \mathrm{A}_{\mathrm{it}-1}\right)+\beta_{3}\left(\mathrm{PPE}_{\mathrm{it}} / \mathrm{A}_{\mathrm{it}-1}\right)+\varepsilon
$$

$\mathrm{TA}_{\mathrm{it}} \quad$ :Total Accrual tahun $\mathrm{t}$

$\mathrm{A}_{\mathrm{it}-1} \quad$ : Total aset perusahaan $\mathrm{i}$ dalam periode tahun $\mathrm{t}-1$

* Corresponding author's e-mail: nawang.kalbuana@stpicurug.ac.id

http://openjournal.unpam.ac.id/index.php/JABI 
Jurnal Akuntansi Berkelanjutan Indonesia - Vol. 3, No. 1, Jan 2020 - Kalbuana;

Yulistian \& Budi

$\Delta \operatorname{Rev}_{\text {it }}$ : Pendapatan tahun t dikurangi pendapatan tahun t-1

$\mathrm{PPE}_{\mathrm{it}}$ : Aset tetap tahun $\mathrm{t}$

$\beta_{1,2,3}$ : Koefisien

$\varepsilon \quad:$ Eror

Tahap ketiga: mencari Nondiscretionary Accruals (NDAit) dengan rumus berikut.

$$
\mathrm{NDA}_{i t}=\beta_{1}\left(1 / A_{i t-1}\right)+\beta_{2}\left(\left(\Delta \operatorname{Rev}_{i t}-\Delta \operatorname{Rec}_{i t} / A_{i t-1}\right)+\beta_{3}\left(P_{P E} / A_{i t-1}\right)+\varepsilon\right.
$$

Keterangan:

$\mathrm{NDA}_{\text {it }}$ : Nondiscretionary Accruals perusahaan i tahun $\mathrm{t}$

$\mathrm{A}_{\mathrm{it}-1} \quad$ : Total aset perusahaan i dalam periode tahun $\mathrm{t}-1$

$\Delta \mathrm{Rev}_{\mathrm{it}}$ : Pendapatan tahun $\mathrm{t}$ dikurangi pendapatan tahun $\mathrm{t}-1$

$\Delta \mathrm{Rec}_{\mathrm{it}}$ : Piutang usaha tahun $\mathrm{t}$ dikurangi piutang usaha tahun $\mathrm{t}-1$

$\mathrm{PPE}_{\mathrm{it}}$ : Aset tetap tahun $\mathrm{t}$

$\beta_{1,2,3}$ : Koefisien

$\varepsilon \quad:$ Eror

Tahap keempat menghitung Discretionary Accruals (DA) dengan rumus berikut.

$$
\mathbf{D A}_{i t}=\left(T A_{i t} / A_{i t-1}\right)-N_{\text {DAt }}
$$

Keterangan:

$\mathrm{DA}_{\text {it }} \quad$ : Discretionary Accruals perusahaan i tahun $\mathrm{t}$

$\mathrm{TA}_{\mathrm{it}} \quad$ : Total Accrual perusahaan i tahun $\mathrm{t}$

$\mathrm{A}_{\mathrm{it}-1} \quad$ : Total aset perusahaan i dalam periode tahun $\mathrm{t}-1$

$\mathrm{NDA}_{\text {it }}$ : Nondiscretionary Accruals perusahaan i tahun $\mathrm{t}$

\section{Metode Analisis Data}

Untuk menguji hipotesis, penelitian ini menggunakan analisis regresi linear berganda. Uji normalitas, uji multikolonieritas, uji heteroskedastisitas, dan uji autokorelasi digunakan untuk mendukung data yang diuji terdistribusi secara normal dan bebas dari asumsi klasik. Sedangkan uji hipotesis meliputi koefisien determinasi, uji F (simultan), dan uji t (uji parsial). Analisis regresi linear berganda dalam penelitian ini adalah :

$$
\mathbf{Y}=\alpha+\beta \mathbf{X}_{1}+\beta \mathbf{X}_{2}+\beta \mathbf{X}_{3}+\beta \mathbf{X}_{4}+\varepsilon
$$

Keterangan:

Y : Manajemen Laba

$\alpha \quad$ : Konstanta

$\beta \quad$ : Koefisien Regresi

$\mathrm{X}_{1} \quad$ : Intellectual Capital

$\mathrm{X}_{2} \quad$ : Kepemilikan Institusional

$\mathrm{X}_{3} \quad$ : Kepemilikan Manajerial

$\mathrm{X}_{4} \quad$ : Kualitas Audit

$\varepsilon \quad:$ Eror 
Jurnal Akuntansi Berkelanjutan Indonesia - Vol. 3, No. 1, Jan 2020 - Kalbuana;

Yulistian \& Budi

\section{ANALISIS DATA DAN PEMBAHASAN}

\section{Hasil Analisis Statistik Deskriptif}

Berikut tersaji tabel yang memuat analisis statistik deskriptif dari penelitian.

Tabel 2: Deskripsi Variabel

\begin{tabular}{lcrrrr}
\hline & N & Minimum & Maximum & \multicolumn{1}{c}{ Mean } & Std. Deviation \\
\hline Manajemen Laba & 70 & 0.0000 & 2.4146 & .069571 & 0.2907837 \\
Intellectual Capital & 70 & 0.0000 & 27.3200 & 2.970083 & 4.5711032 \\
Kepemilikan Institusional & 70 & 0.0000 & 0.8644 & 0.436889 & 0.2994370 \\
Kepemilikan Manajerial & 70 & 0.0000 & 0.8646 & 0.284140 & 0.2978119 \\
Kualitas Audit & 70 & 0.0 & 1.0 & 0.171 & 0.3796 \\
Valid N (listwise) & 70 & & & & \\
\hline
\end{tabular}

Berdasarkan tabel di atas dapat dilihat bahwa sampel diambil dari 70 laporan keuangan selama tahun 2014 - 2018 dari 14 perusahaan transportasi. Variabel manajemen laba memiliki nilai rata-rata 0,069571 dan standar deviasi 0,2907837. Nilai minimum variabel manajemen laba sebesar 0,0000 dan nilai maksimum sebesar 2,4146.

Variabel independen intellectual capital memiliki nilai rata-rata 2,970083 dan standar deviasi 4,5711032. Hal tersebut data diartikan perusahaan dalam sampel penelitian ini khususnya kategori good performers dengan skor VAICTM antara 2,00 sampai 2,99 (Ulum, 2008). Variabel ini memiliki nilai minimum 0,0000 dan nilai maksimum 27,32. Selisih nilai yang tinggi tersebut dapat disebabkan dari beragamnya perlakuan perusahaan dalam memanfaatkan intellectual capital guna meningkatkan nilai tambah perusahaan.

Variabel kepemilikan institusional memiliki nilai rata-rata 0,436889 dan standar deviasi 0,2994370. Hal ini menunjukkan bahwa rata-rata saham perusahaan dalam sampel yang dimiliki oleh pihak institusi sebesar 43,69\%. Nilai minimum variabel ini adalah 0,0000 dan nilai maksimum 0,8644.

Variabel kepemilikan manajerial memiliki nilai rata-rata 0,284140 dan standar deviasi 0,2978119. Hal tersebut menunjukkan bahwa rata-rata saham perusahaan dalam sampel yang dimiliki oleh pihak yang berafiliasi dengan perusahaan maupun entitas anak sebesar $28,41 \%$. Nilai minimum variabel ini adalah 0,0000 dan nilai maksimum 0,8646 .

Variabel kualitas audit memiliki nilai rata-rata sebesar 0,171 dan standar deviasi 0,3796. Nilai maksimum variabel ini adalah 1 dan nilai minimum sebesar 0 . Nilai tersebut merupakan hasil dari variabel dummy untuk laporan keuangan yang diaudit oleh KAP big four dan non big four.

\section{Hasil Uji Asumsi Klasik \\ Uji Normalitas}

Data di transformasi dengan di Ln karena saat uji normalitas model regresi tidak terdistribusi secara normal. 
Jurnal Akuntansi Berkelanjutan Indonesia - Vol. 3, No. 1, Jan 2020 - Kalbuana;

Yulistian \& Budi

Tabel 3: Hasil Uji Kolmogorof-Smirnof setelah transformasi Ln

\begin{tabular}{llr}
\hline & & \multicolumn{1}{c}{ Lnei2 } \\
$\mathrm{N}$ & & 70 \\
\hline Normal Parameters & Mean & -6.2266 \\
& Std. Deviation & 2.55634 \\
Most Extreme Differences & Absolute & 0.091 \\
& Positive & 0.063 \\
& Negative & -0.091 \\
Test Statistic & & 0.091 \\
Asymp. Sig. (2-tailed) & & $0.200^{\mathrm{c}, \mathrm{d}}$ \\
\hline
\end{tabular}

Setelah data ditransformasi nilai Asymp.Sig (2-tailed) dalam tabel sebesar 0,200 di atas nilai signifikansi 0,05 . Hal ini menunjukkan bahwa setelah melakukan transformasi nilai residual ke dalam logaritma natural, model regresi tersebut menjadi terdistribusi secara normal.

\section{Uji Multikolinearitas}

Tabel 4: Hasil Uji Multikolinearitas

\begin{tabular}{llrr}
\hline & & \multicolumn{2}{c}{ Collinearity Statistics } \\
Model & Tolerance & VIF \\
\hline $1 \quad$ (Constant) & & \\
& Intellectual Capital & 0.878 & 1.138 \\
& Kepemilikan Institusional & 0.214 & 4.675 \\
& Kepemilikan Manajerial & 0.215 & 4.641 \\
& Kualitas Audit & 0.881 & 1.135 \\
\hline
\end{tabular}

a. Dependent Variable: Manajemen Laba

Dari tabel dapat dilihat untuk seluruh variabel yang digunakan dalam penelitian ini nilai tolerance yang diperoleh lebih dari 0,1 dan nilai VIF kurang dari 10. Hal ini menunjukkan bahwa tidak terjadi gejala multikolinearitas antar variabel sehingga dapat disimpulkan bahwa model regresi baik dan layak untuk digunakan dalam penelitian.

\section{Uji Autokorelasi}

Tabel 5: Hasil Uji Autokorelasi

\begin{tabular}{llcccc}
\hline Model & $\mathrm{R}$ & R Square & $\begin{array}{c}\text { Adjusted R } \\
\text { Square }\end{array}$ & $\begin{array}{c}\text { Std. Error of the } \\
\text { Estimate }\end{array}$ & $\begin{array}{c}\text { Durbin- } \\
\text { Watson }\end{array}$ \\
\hline 1 & $0.643^{\mathrm{a}}$ & 0.413 & 0.377 & 0.2294740 & 1.746 \\
\hline $\begin{array}{l}\text { a. Predictors: (Constant), Kualitas Audit, Intellectual Capital, Kepemilikan Manajerial, } \\
\text { Kepemilikan Institusional } \\
\text { b. Dependent Variable: Manajemen Laba }\end{array}$ & & & & \\
\end{tabular}

Dari tabel diperoleh nilai d (DW) sebesar 1,746. Nilai tersebut kemudian dibandingkan dengan nilai pada tabel Durbin-Watson untuk jumlah variabel 
Jurnal Akuntansi Berkelanjutan Indonesia - Vol. 3, No. 1, Jan 2020 - Kalbuana; Yulistian \& Budi

independen (k) 4 dan jumlah sampel (n) 70. Diperoleh nilai dL sebesar 1,4943 dan nilai dU 1,7351. Nilai d 1,746 lebih besar dari nilai dL 1,4943 dan lebih kecil dari nilai 4-dU yaitu 2,2649. Sehingga dapat disimpulkan bahwa model regresi tersebut tidak terjadi autokorelasi dan baik digunakan dalam penelitian.

\section{Uji Heteroskedastisitas}

Karena grafik scatterplot menunjukkan pola tertentu dan mengumpul di antara angka -2 dan 0 pada sumbu $X$ dan angka 0 pada sumbu $Y$. Hal tersebut menunjukkan terjadinya gejala heteroskedastisitas pada model regresi.

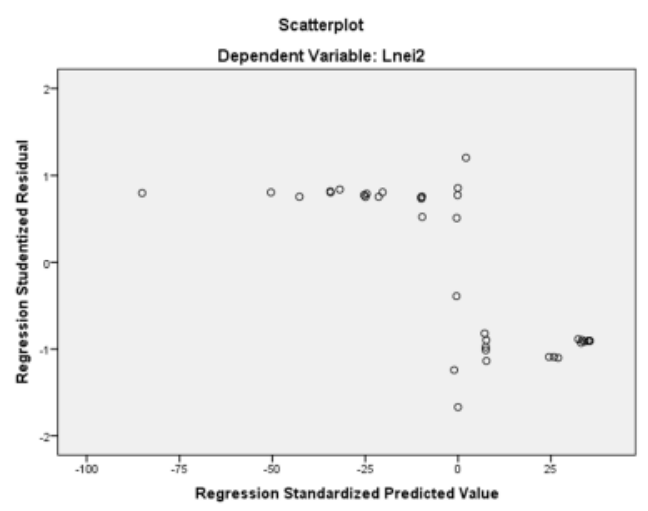

\section{Gambar 2: Hasil Uji Heteroskedastisitas}

\section{Hasil Uji Heteroskedastisitas setelah Uji Park}

Setelah dilakukan transformasi variabel ke dalam logaritma natural, terlihat pada gambar 2 titik-titik menyebar dalam grafik scatterplot. Hal ini menunjukkan bahwa setelah dilakukan uji park untuk menguji heteroskedastisitas, model regresi layak digunakan dalam penelitian.

\section{Hasil Analisis Regresi Linier Berganda}

Tabel 6: Hasil Analisis Regresi Coefficients $^{\mathrm{a}}$

\begin{tabular}{|c|c|c|c|c|c|}
\hline \multirow[b]{2}{*}{ Model } & \multicolumn{2}{|c|}{$\begin{array}{l}\text { Unstandardized } \\
\text { Coefficients }\end{array}$} & \multirow{2}{*}{$\begin{array}{c}\text { Standardized } \\
\text { Coefficients } \\
\text { Beta }\end{array}$} & \multirow[b]{2}{*}{$\mathrm{t}$} & \multirow[b]{2}{*}{ Sig. } \\
\hline & $\mathrm{B}$ & Std. Error & & & \\
\hline (Constant) & 0.034 & 0.138 & & 0.250 & 0.804 \\
\hline Intellectual Capital & 0.041 & 0.006 & 0.650 & 6.413 & 0.000 \\
\hline Kepemilikan Institusional & -0.064 & 0.199 & -0.066 & -0.321 & 0.749 \\
\hline Kepemilikan Manajerial & -0.160 & 0.200 & -0.163 & -0.798 & 0.428 \\
\hline Kualitas Audit & -0.084 & 0.078 & -0.109 & -1.079 & 0.284 \\
\hline
\end{tabular}

a. Dependent Variable: Manajemen Laba 
Jurnal Akuntansi Berkelanjutan Indonesia - Vol. 3, No. 1, Jan 2020 - Kalbuana;

Yulistian \& Budi

Berdasarkan hasil analisis regresi linier berganda pada tabel di atas variabel manajemen laba memiliki nilai konstanta sebesar 0,034. Hal tersebut menunjukkan bahwa apabila variabel independen konstan, maka nilai manajemen laba sebesar 0,034. Untuk menguji pengaruh variabel intellectual capital, kepemilikan institusional, kepemilikan manajerial, dan kualitas audit terhadap manajemen laba maka dapat disimpulkan dalam sebuah persamaan berikut:

$$
\text { DA }=0.034+0.041 \text { IC }-0.064 \text { INST }-0.160 \text { MNJR }-0.084 \text { KA + } \varepsilon
$$

a. $\mathbf{H}$

\section{Koefisien Determinasi (Adjusted $\boldsymbol{R}^{2}$ )}

Tabel 7: Hasil Uji Koefisien Determinasi

\begin{tabular}{|c|c|c|c|c|c|}
\hline Model & $\mathrm{R}$ & R Square & $\begin{array}{c}\text { Adjusted R } \\
\text { Square }\end{array}$ & $\begin{array}{l}\text { Std. Error of } \\
\text { the Estimate }\end{array}$ & Durbin-Watson \\
\hline 1 & $0.643^{\mathrm{a}}$ & 0.413 & 0.377 & 0.2294740 & 1.746 \\
\hline $\begin{array}{l}\text { a. Predi } \\
\text { Manajer } \\
\text { b. Depe } \\
\text { Sumber }\end{array}$ & $\begin{array}{l}\text { rs: }(\mathrm{Co} \\
\text {, Kepe } \\
\text { ent Var } \\
\text { ata sekı }\end{array}$ & $\begin{array}{l}\text { istant), Kuc } \\
\text { milikan Ins } \\
\text { iable: Mana } \\
\text { inder yang }\end{array}$ & $\begin{array}{l}\text { litas Audit, In } \\
\text { itusional } \\
\text { emen Laba } \\
\text { iolah }\end{array}$ & lectual Capita & ikan \\
\hline
\end{tabular}

Pada tabel 7 dapat dilihat nilai koefisien determinasi (Adjusted R2) sebesar 0,377. Hal ini menunjukkan bahwa variabel intellectual capital, kepemilikan institusional, kepemilikan manajerial dan kualitas audit berpengaruh sebesar $37,7 \%$ terhadap manajemen laba. Variabel lain yang mempengaruhi manajemen laba yang tidak terdapat dalam penelitian ini sebesar $62,3 \%$.

\section{Uji Statistik F (Uji Simultan)}

Berdasarkan tabel didapat nilai dari uji $\mathrm{F}$ hitung sebesar 11,449. Hal ini diartikan nilai uji $\mathrm{F}$ yang diperoleh lebih dari nilai $\mathrm{F}$ tabel yaitu 2,513. Sehingga dapat diperoleh kesimpulan bahwa variabel intellectual capital, kepemilikan institusional, kepemilikan manajerial dan kualitas audit secara simultan berpengaruh terhada manajamen laba. Dengan demikian H1 diterima

Tabel 8: Hasil Uji Statistik F

\begin{tabular}{llrrrrr}
\multicolumn{7}{c}{ ANOVA $^{\mathbf{a}}$} \\
\hline Model & & Sum of Squares & df & Mean Square & F & Sig. \\
\hline 1 & Regression & 2.412 & 4 & 0.603 & 11.449 & $0.000^{\mathbf{b}}$ \\
& Residual & 3.423 & 65 & 0.053 & & \\
& Total & 5.834 & 69 & & & \\
\hline
\end{tabular}

a. Dependent Variable: Manajemen Laba

b. Predictors: (Constant), Kualitas Audit, Intellectual Capital, Kepemilikan Manajerial,

Kepemilikan Institusional

Sumber: data sekunder yang diolah

* Corresponding author's e-mail: nawang.kalbuana@stpicurug.ac.id

http://openjournal.unpam.ac.id/index.php/JABI 
Jurnal Akuntansi Berkelanjutan Indonesia - Vol. 3, No. 1, Jan 2020 - Kalbuana;

Yulistian \& Budi

\section{Uji Statistik t (Uji Parsial)}

Tabel 9: Hasil Uji Statistik t

\begin{tabular}{|c|c|c|c|c|c|}
\hline \multirow[b]{2}{*}{ Model } & \multicolumn{2}{|c|}{$\begin{array}{l}\text { Unstandardized } \\
\text { Coefficients }\end{array}$} & \multirow{2}{*}{$\begin{array}{c}\text { Standardized } \\
\text { Coefficients } \\
\text { Beta }\end{array}$} & \multirow[b]{2}{*}{$\mathrm{t}$} & \multirow[b]{2}{*}{ Sig. } \\
\hline & $\mathrm{B}$ & Std. Error & & & \\
\hline (Constant) & 0.034 & 0.138 & & 0.250 & 0.804 \\
\hline Intellectual Capital & 0.041 & 0.006 & 0.650 & 6.413 & 0.000 \\
\hline Kepemilikan Institusional & -0.064 & 0.199 & -0.066 & -0.321 & 0.749 \\
\hline Kepemilikan Manajerial & -0.160 & 0.200 & -0.163 & -0.798 & 0.428 \\
\hline Kualitas Audit & -0.084 & 0.078 & -0.109 & -1.079 & 0.284 \\
\hline
\end{tabular}

a. Dependent Variable: Manajemen Laba

Berdasarkan tabel 9, dapat diketahui nilai t hitung yang diperoleh dari variabel intellectual capital sebesar 6,413 dan nilai koefisien sebesar 0,041. Nilai t hitung ini lebih besar dibandingkan dari nilai t tabel yang diperoleh, yaitu 1,66827. Hal ini menunjukkan bahwa variabel intellectual capital berpengaruh positif terhadap manajemen laba. Dengan demikian $\mathrm{H} 2$ dapat diterima.

Variabel kedua yaitu kepemilikan institusional memiliki nilai t hitung sebesar 0,321 dan nilai koefisien sebesar -0,064. Nilai t hitung tersebut lebih kecil daripada $t$ tabel yang diperoleh $(1,66792)$. Hal ini menunjukkan bahwa variabel kepemilikan institusional tidak berpengaruh terhadap manajemen laba. Dengan demikian H3 ditolak. Hasil dari penelitian ini sejalan dengan penelitian yang dilakukan oleh Guna \& Herawaty (2010), Agustia (2013), Mahariana \& Ramantha (2014), Sari \& Putri (2014), dan Khairani \& Wimelda (2017). Besarnya kepemilikan saham seharusnya mampu membuat pihak institusional mengontrol kegiatan operasional, namun realitanya kepemilikan institusional tidak mampu membatasi adanya manajemen laba (Agustia, 2013).

Variabel ketiga yaitu kepemilikan manajerial memiliki nilai t hitung sebesar 0,798 dan nilai koefisien sebesar $-0,160$. Nilai t hitung lebih kecil dari nilai t tabel yang didapat. Hal ini menunjukkan bahwa kepemilikan manajerial tidak berpengaruh terhadap manajemen laba. Dengan demikian H4 ditolak. Hasil penelitian ini sejalan dengan penelitian yang dilakukan oleh Guna \& Herawaty (2010), Abed et al. (2012), dan Agustia (2013). Namun penelitian ini bertentangan dengan hasil dari penelitian yang dilakukan oleh Antonia (2008), Mahariana \& Ramantha (2014), dan Sari \& Putri (2014) yang menyatakan bahwa kepemilikan manajerial berpengaruh negatif terhadap manajemen laba. Menurut Sari \& Putri (2014) kepemilikan manajerial mampu menurunkan tindakan manajemen laba dengan menggunakan kemampuan manajer dalam melindungi sahamnya agar tidak jatuh akibat tindakan manajemen laba.

Variabel terakhir yaitu kualitas audit memiliki nilai t hitung sebesar -1,079 dan nilai koefisien sebesar $-0,084$. Nilai t hitung yang didapat lebih kecil dari nilai $t$ tabel. Hal ini menunjukkan bahwa kualitas audit tidak berpengaruh terhadap manajemen laba. Dengan demikian H5 ditolak. Hasil ini sejalan dengan penelitian yang dilakukan oleh Guna \& Herawaty (2010) dan Wiryadi \& Sebrina (2013).

* Corresponding author's e-mail: nawang.kalbuana@stpicurug.ac.id http://openjournal.unpam.ac.id/index.php/JABI 
Jurnal Akuntansi Berkelanjutan Indonesia - Vol. 3, No. 1, Jan 2020 - Kalbuana;

Yulistian \& Budi

Perusahaan yang diaudit oleh KAP besar belum tentu dapat membatasi terjadinya tindakan manajemen laba (Wiryadi \& Sebrina, 2013).

\section{KESIMPULAN DAN SARAN}

Dari penelitian yang telah dilakukan diperoleh kesimpulan bahwa variabel intellectual capital, tata kelola perusahaan yang diproksikan dengan kepemilikan institusional, dan kepemilikan manajerial dan kualitas audit secara simultan berpengaruh terhadap manajemen laba pada perusahaan transportasi. Variabel intellectual capital berpengaruh positif terhadap manajemen laba. Sementara variabel kepemilikan institusional, kepemilikan manajerial, dan kualitas audit terbukti tidak berpengaruh terhadap manajemen laba. Dengan demikian hanya $\mathrm{H}_{1}$ dan $\mathrm{H}_{2}$ yang diterima.

Berdasarkan hasil penelitian yang diperoleh, variabel intellectual capital berpengaruh positif tehadap manajemen laba. Hal ini membuktikan secara empiris bahwa modal intelektual dapat menjadi indikator pemicu terjadinya praktik manajemen laba.

Berdasarkan hasil penelitian yang diperoleh, variabel tata kelola perusahaan yang diproksikan dengan kepemilikan institusional dan kepemilikan manajerial, tidak berpengaruh terhadap manajemen laba. Tata kelola perusahaan dengan menggunakan struktur kepemilikan saham dari pihak institusional yang seharusnya mampu untuk mengontrol kegiatan operasional perusahaan tidak terbukti dapat membatasi tindakan manajemen laba. Begitu pula dengan kepemilikan saham atas pihak manajerial perusahaan yang tidak memiliki pengaruh untuk mencegah terjadinya praktik manajemen laba.

Berdasarkan hasil penelitian yang diperoleh, variabel kualitas audit tidak berpengaruh terhadap manajemen laba. Laporan keuangan yang diaudit oleh KAP big four pun tidak terbukti dapat membatasi perilaku manajemen laba yang dilakukan oleh perusahaan.

\section{DAFTAR PUSTAKA}

Abed, S., Al-Attar, A., \& Suwaidan, M. (2012). Corporate governance and earnings management: Jordanian evidence. International Business Research, 5(1), 216.

Agustia, D. (2013). Pengaruh faktor good corporate governance, free cash flow, dan leverage terhadap manajemen laba. Jurnal Akuntansi dan Keuangan, 15(1), 27-42.

Antonia, E. (2008). Analisis Pengaruh Reputasi Auditor, Proporsi Dewan Komisaris Independen, Leverage, Kepemilikan Manajerial dan Proporsi Komite Audit Independen terhadap Manajemen Laba (Studi pada

* Corresponding author's e-mail: nawang.kalbuana@stpicurug.ac.id http://openjournal.unpam.ac.id/index.php/JABI 
Jurnal Akuntansi Berkelanjutan Indonesia - Vol. 3, No. 1, Jan 2020 - Kalbuana;

Yulistian \& Budi

Perusahaan Manufaktur di Bursa Efek Indonesia Periode 2004-2006) (Doctoral dissertation, program Pascasarjana Universitas Diponegoro).

Boekestein, B. (2006). "The relation between intellectual capital and intangible assets of pharmaceutical companies". Journal of Intellectual Capital. Vol. 7 No. 2. pp. 241-253.

Dechow, P. M., Sloan, R. G., \& Sweeney, A. P. (1995). Detecting earnings management. Accounting review, 193-225.

Fatima, H. (2012). Analisis Pengaruh Modal Intelektual Terhadap Kinerja Perusahaan di Indonesia (Skripsi, Program Sarjana Universitas Indonesia).

Freeman, R.E., and Reed. (1983). "Stockholders and stakeholders: a new perspective on corporate governance". Californian Management Review. Vol 25. No. 2. pp. 88-106.

Guna, W. I., \& Herawaty, A. (2010). Pengaruh mekanisme good corporate governance, independensi auditor, kualitas audit dan faktor lainnya terhadap manajemen laba. Jurnal bisnis dan akuntansi, 12(1), 53-68.

Herawaty, V. (2008). Peran praktek corporate governance sebagai moderating variable dari pengaruh earnings management terhadap nilai perusahaan. Jurnal akuntansi dan keuangan, 10(2), 97-108.

Khairani, M., \& Wimelda, L. (2017). Apakah Tata Kelola Perusahaan dan Gambaran Perusahaan Publik Menurunkan Praktik Manajemen Laba? Konferensi Ilmiah Akuntansi IV.

Jensen, M. C. and Meckling, W.H. (1976). Theory of The Firm: Managerial Behavior, Agency Cost and Ownership Structure. Journal of Financial Economics, 3, 305-360

Mahariana, I. D. G. P., \& Ramantha, I. W. (2014). Pengaruh Kepemilikan Manajerial dan Kepemilikan Institusional terhadap Manajemen Laba Pada Perusahaan Manufaktur di BEI. E-Jurnal Akuntansi, 688-699.

Prastowo, Y. (2019). Kasus Garuda dan Misteri Akuntansi. Dari https://money.kompas.com/read/2019/07/18/152000526/kasus-garudadan-misteri-akuntansi?page=all, diakses pada 7 November 2019.

Sari, A. I. P., \& Putri, I. G. A. D. (2014). Pengaruh Mekanisme Corporate Governance Pada Manajemen Laba. E-Jurnal Akuntansi, 94-104.

Sawarjuwono, T., \& Kadir, A. P. (2003). Intellectual Capital: Perlakuan, Pengukuran, dan Pelaporan (Sebuah Library Research). Jurnal Akuntansi \& Keuangan 5(1), 35-57.

Scott, W. R. (2011). Financial Accounting Theory (Sixth ed.). Canada: Person Prentince Hall.

* Corresponding author's e-mail: nawang.kalbuana@stpicurug.ac.id http://openjournal.unpam.ac.id/index.php/JABI 
Jurnal Akuntansi Berkelanjutan Indonesia - Vol. 3, No. 1, Jan 2020 - Kalbuana;

Yulistian \& Budi

Ulum, I. (2009). Intellectual Capital (Konsep dan Empiris). Yogyakarta: Graha Ilmu.

Ulum, I. (2008). Intellectual capital performance sektor perbankan di Indonesia. Jurnal Akuntansi dan Keuangan, 10(2), 77-84.

Yudhanti, C. B. H., \& Shanti, J. C. (2011). Intellectual Capital dan Ukuran Fundamental Kinerja Keuangan Perusahaan. Jurnal Akuntansi dan Keuangan, 13(2), 57-66.

https://idnfinancials.com/ Diakses pada 11 Oktober 2019 